\title{
構造用鋼材の延性き裂発生条件 THE CRITERION FOR DUCTILE CRACK INITIATION IN STRUCTUAL STEELS
}

\author{
小野徹郎*, 佐藤篤司**, 横川貴之***, 相川直子**** \\ Tetsuro ONO, Atsushi SATO, Takayuki YOKOKAWA \\ and Naoko AIKAWA
}

\begin{abstract}
Recently, high strength steel and cold-formed steel are used on structural members, which have poor capacity for plastic strain. So there is a possibility that deformation capacity at the beam end is limited by not local buckling but brittle fracture. Because brittle fracture is brought on ductile crack, saving the occurrence of it lead to preventing brittle fracture.

Purposes of this paper are to understand the initiation of ductile crack at the notch tip by experiment, and to clarify the distribution of stress and strain at the notch section by FEM analysis. As a result, the criterion for ductile crack initiation is proposed.
\end{abstract}

Keywords : Structual Steels, Brittle Fracture, Ductile Crack, Stress Triaxiallity,

Total Equivalent Plastic Strain, Yield Ratio

構造用鎆材，脆性破壊，延性き裂，有限要素法解析，応力三軸度，相当塑性歪，降伏比

\section{1. 序}

近年発生した兵庫県南部地震,ノースリッジ地震において、建築物 に数多くの被害が報告され[1]、鋼構造建築物に関しても例外ではな く鉄骨部材の脆性破壊が問題視され、安全性が大きく問われること となった。両地震のような大規模都市直下型地震においても、現行 の新耐震設計法の基本理念である人命確保のための骨組倒壊防止は 達成されなければならない。しかし、新耐震設計法の保有耐力接合 では、梁端が素材の最大耐力を発揮すること、つまり最大耐力に至 るまでの塑性変形エネルギー吸収を前提としているが、実際には接合 部の性質上,溶接欠陷,スカラップやエンドタブ等の応力集中が存在し [2]、期待される最大耐力, エネルギ一吸收を発揮することなく脆性的 に破壊に至り、限界づけられる可能性がある。このような破壊現象 に対する研究は、近年になって精力的に行われるようになったのが 現状であり、今後、同じような被害を繰返さないよう耐震性能を確 保するためには、部材が期待される塑性変形能力を発揮する以前に 破断に至る脆性破壊の防止は不可欠であり、そのためには脆性破断 の要因を明らかにし、それらの影響を定量的に捉える必要がある。

これまでの研究により、地震等による鉄骨部材の脆性破壊は、3 段階の破壊プロセスから構成されていることが明らかにされている。 まず、溶接接合部などの形状的不連続部において歪集中と多軸応力
拘束が相互に関与し延性き裂が発生する。その延性き裂が部材の塑 “性変形の過程で安定的に成長し、最終的に延性き裂の大きさが限界 点に到達することによって急激に脆性破壊に転化する [2],[3]。これら 破壊現象を考慮した場合、様々な段階での設計が考えられるが、延 性き裂の発生が直ちに脆性破壊に繋がるという実験結果[4]-[7]もあり、 また延性き裂から脆性破壊への転化条件が未だ定量的に未解明な現 状においては、延性き裂の安定成長段階での塑性変形能力を期待す ることは非常に危険である。よって、延性き裂の発生要因を定量的 に把握し、その発生を防止する技術体系が必要とされる[2],[13],[16],[27]。 近年、高張力鎆や冷間成形鋼等の塑性变形能力に乏しい鋼材の使 用，建築部材の極厚化等によって局部座屈よりも脆性破壊によって 柱梁接合部の変形能力が限界づけられる可能性がでてきたことから: その一貫として脆性破壊の起点となる延性破壊に関する研究が行わ れるようになった。桑村らは、延性き裂の発生について一連の研究

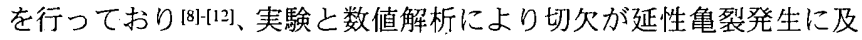
ぼす影響を考察し、切欠底最小断面内の応力三軸度のピーク值と素 材の一様伸びを指標とした延性亀裂発生条件式の提案をしている。 また、この延性亀裂発生条件の柱ダイヤフラムと梁フランジの接合部を 模式化した鋼板への適応も試み、条件式に補正係数を導入すること で適応範囲を拡大している。豊田らもSN490B材について延性き裂
* 名古屋工業大学工学部社会開発工学科建築系 教授.工博

** 名古屋工業大学大学院 大学院生・工修

(日本学術振興会 特別研究貝)

***十ヨ夕自動車(侏) 工修

**** 名古屋工業大学大学院 大学院生
Prof., Dept. of Architecture, Nagoya Institute of Technology, Dr. Eng. Graduate Student, Nagoya Institute of Technology, M. Eng. (JSPS Research Fellow)

TOYOTA Motor Corporation, M. Eng.

Graduate Student, Nagoya Institute of Technology 
発生についての評価を行い[[13],[14]、延性き裂発生点となる歪集中部位 に注目し、その点における相当塑性歪が一定值に到達することでき 裂が発生するとしている。島貫らも同様の研究を行い[15],[16]、延性き 裂発生時の相当塑性歪は応力三軸度の上昇によって低下することを 明らかにし、その時の応力三軸度と相当塑性歪の関係式を提案して いる。しかし、対象としている亀裂発生現象は、脆性破壊の起点と なる応力集中部表面でなく内部での発生を対象としている。

建築部材での延性亀裂発生は、発生部位の応力及び歪状態に支配 されていると考えられ[17]-199]、その相互関係を考慮して延性亀裂発 生条件を考察すべきであり、また、多様化する鋼材との対応につい ても考察していく必要がある。本研究では、延性き裂発生点となる 柱梁接合部のスカラップ等の応力集中部を想定し、建築構造物に用い られる6種の構造用鋼材を対象として切欠形状をパラメータとした延 性き裂発生実験を行い、切欠の幾何学的形状が各素材の延性き裂発 生歪に及ぼす影響を把握する。また、有限要素法による数值解析を 行い試験片断面内部の応力歪状態を明らかにし、延性き裂発生条件 の提案を行う。さらに、延性き裂発生条件を柱梁接合部の塑性変形 限界として適用する基礎的研究として、試験片の幾何学的形状と素 材特性より求められる延性き裂発生歪推定式の提案を行い、素材で の延性き裂発生に及ぼす重要な素材特性を明らかにする。

\section{2. 延性き裂発生実験}

\section{2-1. 実験概要}

本研究では、表 1 に示す 6 種類の構造用鋼材を対象とする。図 1 は 素材試験結果、表1はそれより得られる各素材の機械的性質である。

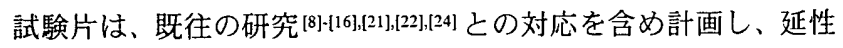
き裂発生点となる接合部のスカラップ底, エンドタブ等の形状的不連 続部を想定し、図 2 に示す平行部長さ $30 \mathrm{~mm}$ の円周切欠を有する丸 棒試験片を採用した。延性き裂は多軸応力拘束と歪集中が相互に関 与して発生することが確認されている[8]-[19],[21],[22]。そこで、試験片 断面内の応力と歪の状態を変化させるため切欠形状をパラメータと し、切欠半径 $\mathrm{R}=0.25,0.50,1.0,2.0,10.0(\mathrm{~mm})$ の 5 種類, 切欠深さ $\mathrm{d}=1.0,2.0(\mathrm{~mm})$ の 2 種類を設定した。表 2 に実験変数の組合せを示 す。切欠底最小断面直径は $2 \mathrm{a}=14(\mathrm{~mm})$ で一定とした。き裂発生の不 確定性を考慮し試験片は各 2 本づつ用意し、試験片総数は平滑材 $(\mathrm{R}=$ Infinity, $\infty)$ を含めて 90 本となる。

試験には、写真 1 に示すMTS 社製サーボ高精度試験機 (最大荷重 $250 \mathrm{kN})$ を用いた。荷重 $P$ は試験機に内臓されたロードセルによって、 公称歪度 ${ }_{\mathrm{n}} \varepsilon$ は試験片平行部に取付けた変位計(標点間距離 $25 \mathrm{~mm}$ )に よって測定した。また、延性き裂は切欠底に発生することが予想さ れ、切欠底を通る最小断面の応力と歪状態を把握することが重要と なる。そこでKEYENCE社製レーザ式外径変位計を用いて載荷中の

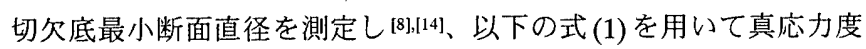
,$\sigma\left(\mathrm{N} / \mathrm{mm}^{2}\right)$, 真丕度 $\varepsilon$ を算出する。

$$
{ }_{n} \sigma=\frac{4 P}{\pi \phi^{2}},{ }_{i} \varepsilon=2 \ln \left(\frac{\phi_{0}}{\phi}\right)
$$

$P$ : 引張荷重 $(\mathrm{N}), \phi:$ 最小断面直径 $(\mathrm{mm}), \phi_{0}$ : 初期最小断面直径 $(\mathrm{mm})$ 延性き裂の発生挙動は、写真 2 に示すように試験中の切欠底表面 を KEYENCE 社製 CCD 搭載マイクロスコープにより 50 倍程度の倍率 で観測することにより確認した ${ }^{[8],[14]}$ 。た、数本の試験片は載荷途

中で除荷し縦に切断して、縦断面を観測することにより延性き裂発 生挙動の把握及びその発生歪の特定を行った [8],[13],[21],[2]],[28]。

\section{2-2. 実験結果}

図 3 にSN490B について公称応力度 ${ }_{n} \sigma$ - 歪度 ${ }_{n} \varepsilon$ 関係及び延性き裂発 生歪 $\varepsilon_{\text {crack }}$ を示す。また、写真3に延性き裂発生状況を示す[8]:113],[2]],[22],[28]。 図3(a) は切欠半径 R を, 図3(b) は切欠深さdをパラメー夕に比較す

表 1 機械的性質

\begin{tabular}{|c|c|c|c|c|c|c|c|c|c|}
\hline Material & $\begin{array}{c}\mathrm{E} \\
\left(\mathrm{kN} / \mathrm{mm}^{2}\right)\end{array}$ & $\begin{array}{c}{ }_{n} \sigma_{y} \\
\left(N / m^{2}\right)\end{array}$ & $\begin{array}{l}{ }_{n} \varepsilon_{y} \\
(\%)\end{array}$ & $\begin{array}{c}{ }_{n} \sigma_{\mathrm{u}} \\
\left(\mathrm{N} / \mathrm{mm}^{2}\right)\end{array}$ & $\begin{array}{l}\mathrm{n}^{\varepsilon_{\mathrm{u}}} \\
(\%)\end{array}$ & Y.R. & $\begin{array}{c}\text { Elong. } \\
(\%)\end{array}$ & $\begin{array}{c}\text { S.E. } \\
\left(\mathrm{N} / \mathrm{m}^{2} \mathrm{~m}^{2}\right)\end{array}$ & $\begin{array}{l}\text { S.C.E. } \\
\left(\mathrm{N} / \mathrm{mm}^{2}\right)\end{array}$ \\
\hline SS 400 & 212 & 281 & 0.132 & 443 & 20.6 & 0.634 & 56.8 & 82.0 & 8.99 \\
\hline SM490A & 209 & 361 & 0.173 & 532 & 18.4 & 0.679 & 52.0 & 88.0 & 9.05 \\
\hline SN $400 B$ & 213 & 275 & 0.129 & 446 & 21.3 & 0.616 & 54.8 & 85.5 & 9.12 \\
\hline SN490B & 214 & 366 & 0.171 & 527 & 18.1 & 0.695 & 54.5 & 87.1 & 7.65 \\
\hline HT590 & 217 & 585 & 0.269 & 676 & 7.89 & 0.866 & 43.3 & 51.3 & 0.959 \\
\hline HT780 & 210 & 838 & 0.399 & 890 & 7.09 & 0.942 & 42.6 & 60.7 & 0.497 \\
\hline
\end{tabular}

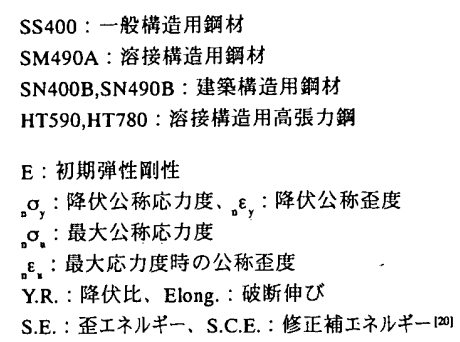

S.E. : 歪エネルギー、S.C.E. : 修正補エネルギー1200

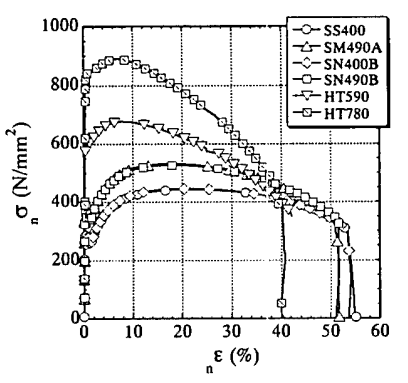

図1 素材引張試験結果

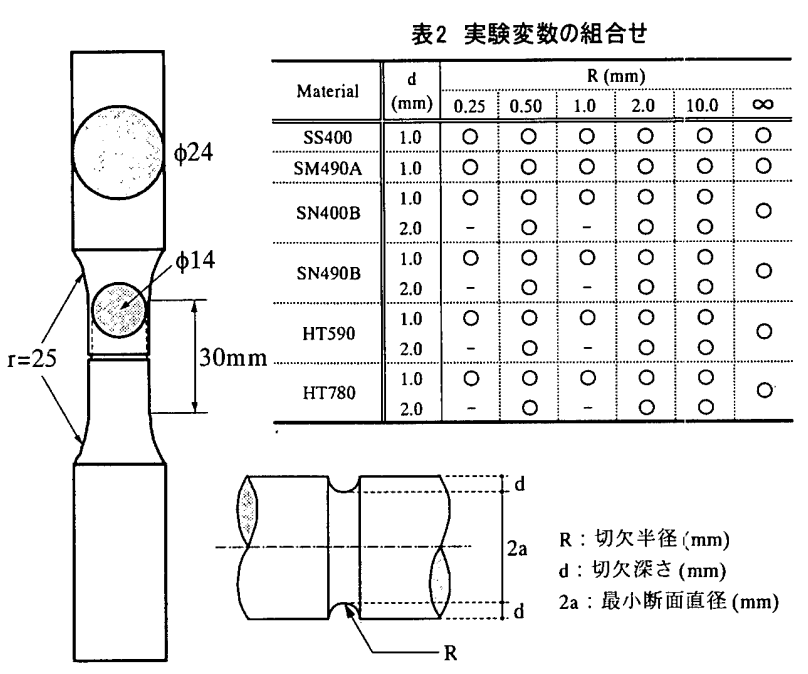

図2 試験片形状及び切欠形状

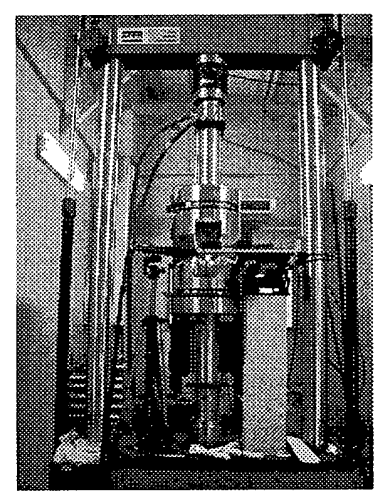

写真1 MTS社製サーボ高精度試験機

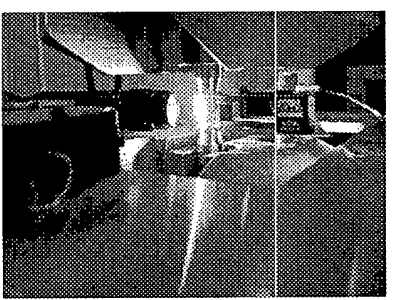

写真 2 き裂䅐測 
る。図3(a)から分かるように従来の知見 $[1 \cdot 1,[14],[21]$ と同様、延性き裂 発生歪 $\varepsilon_{\mathrm{n}}$ rack 比次半径 R の減少に伴い小さくなっている。今回の 実験では、素材に関わらず切欠の鋭い切欠半径 R $0.25,0.50$ の形状で は、最大公称応力度時の歪度 ${ }_{\mathrm{n}} \varepsilon_{\mathrm{u}}$ に達する前の比較的早い段階で写 真3(a),(b) のような延性き裂が切欠底表面に明瞭に発生し、塑性変 形の過程で試験片内部に進展し破断に至った。切欠半径 R1.0,2.0

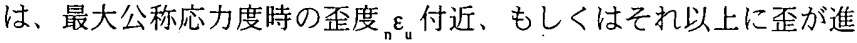
行した後に切欠底表面に延性き裂が発生した。切欠の鈍いR10.0で は、破断直前に耐力が急激に低下し、その時点で載荷を中断するこ とにより写真3(c)に示すように試験片中央部に延性き裂が発生した ことが確認された。切欠底表面に延性き裂が発生した切欠半径 R0.25 2.0 の試験片では、切欠半径の増加に伴って延性き裂は表 面に顕在化しにくくなる。また、各特性值についてみると、切欠半

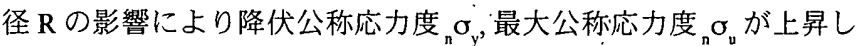
ている。切欠半径 R10.0よりR2.0の方が強度上昇は大きく、切欠半 径Rが小さいほど強度が上昇するように見えるが、R2.0以下では最 大公称応力度 $\sigma_{u}$ にとんど違いは見られず頭打ちになっている。 これは切欠半径Rが小さいほど延性き裂が早期に発生し、それが進 展して断面欠損が進んだため応力の上昇が抑えられたと考えられ る。図3(b)から分かるように、切欠深さdが深いほど切久の影響が 強く、強度の上昇, 伸びの低下が著しく、延性き裂発生歪 $\varepsilon_{\mathrm{n}}$ crack は切 欠が深い $\mathrm{d} 2.0$ の方が小さい傾向が見られる。最大応力度時の歪度 ${ }_{n} \varepsilon_{\mathrm{u}}$ もd2.0の方が $\mathrm{d} 1.0$ に比べ小さい值を示している。

\section{2-3. 延性き裂発生歪の把握}

図 4 に縦軸に延性き裂発生公称歪 $\varepsilon_{\mathrm{n}}$ crack $と り 、$ 横軸 (対数軸) に 切欠半径 R との関係を示す。図4(a) に示したSN490Bの結果から分

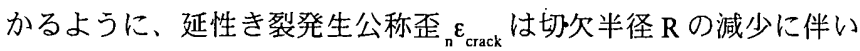
小さくなり、また切欠深さ $\mathrm{d}$ が梁いほど小さくなる傾向が見られ る。これらの傾向は、対象とした全ての素材について同様であっ

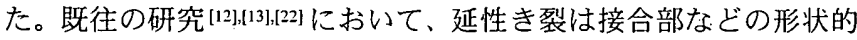
不連続部において歪集中と三軸応力拘束が相互に関与し発生するこ とが明らかになっているため、切欠半径 $\mathrm{R} か ゙$ 小さく, 媣さ $\mathrm{d}$ が深い ほど切欠底断面に歪が集中し、三軸応力拘束が高くなっていると考 えられる。また、対象とした全素材を示した図4(b)をみると切欠半 径Rによらず塑性变形能力に劣る高張力鋼は、他の軟鋼と比較する と延性き裂発生公称歪 $\varepsilon_{\text {crack }}$ が小さいことが分かる。つまり、従来の

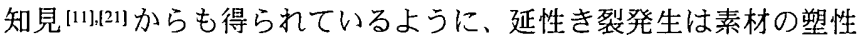
変形能力と相関がある思われる。

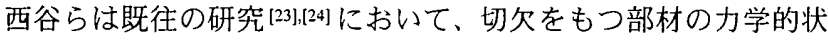
態の笪しさを評価する工学的手法として「線形切欠力学」を提案 し、円周切欠を有する高張力鋼の引張破断条件を検証している。そ

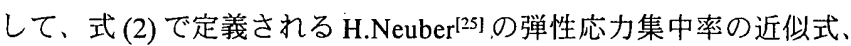
弾性応力集中係数 $K$ を用いることで、鋼材の引張破断が整理できる としている。

$$
K=1+2 \sqrt{\frac{\dot{d}}{R}}
$$

$R:$ 切欠半径, $d:$ 切欠深さ

そこで、弾性応力集中係数 $K$ を用いて延性き裂発生公称歪 ${ }_{\mathrm{n}} \varepsilon_{\text {crack }}$ の考察を行う。図5に延性き裂発生公称歪 $\varepsilon_{\mathrm{c} \text { crack }}$ を各素材の降伏公称 歪度 $\varepsilon_{\mathrm{n} y)}$ で無次元化した值と弾性応力集中倸数の逆数 $1 / \mathrm{K}$ の関係を
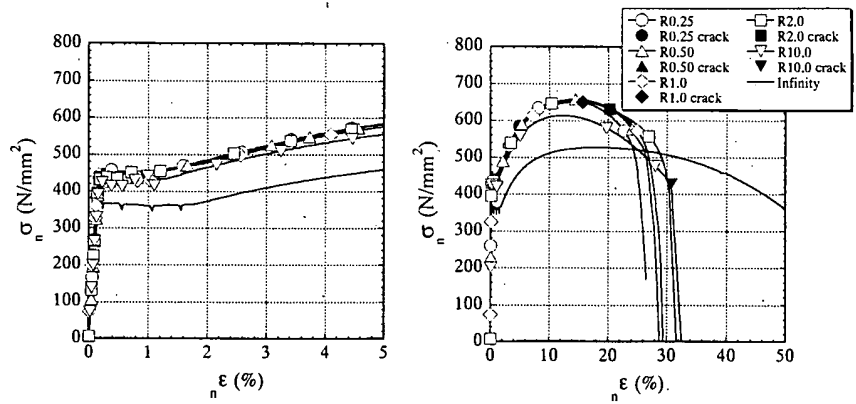

(a) SN4908-R 比較(d1.0)
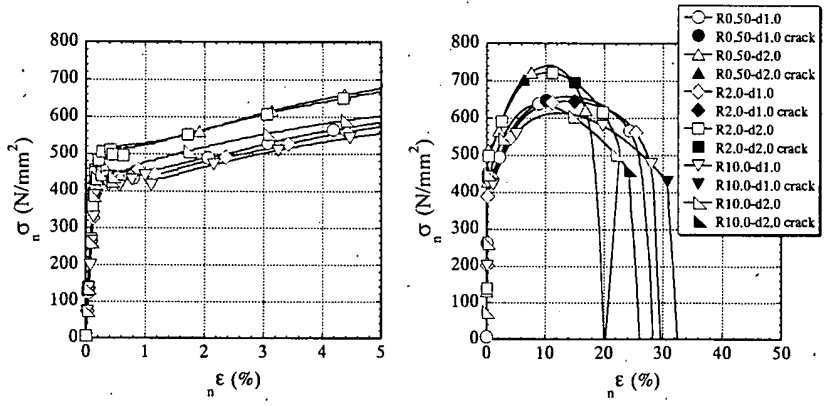

(b) SN490B-d 比較

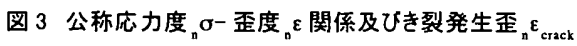

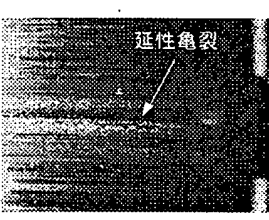

（a）切欠底表面

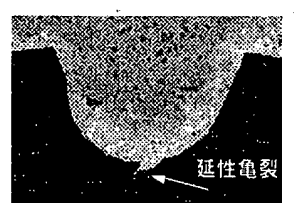

(b) 切欠底断面

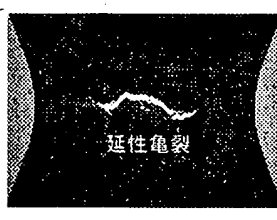

（c）試験片䋊断面(R10.0) 写真3 延性き裂発生状況

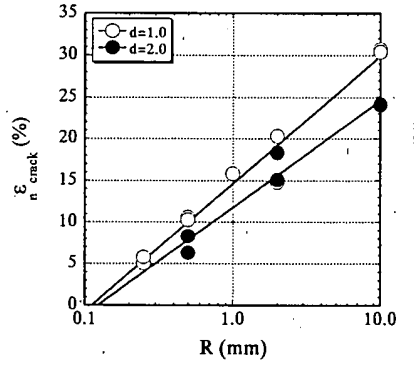

(a) $\varepsilon_{\mathrm{n}} \varepsilon_{\text {crack }}-\mathrm{R}$ 関係(SN490B)

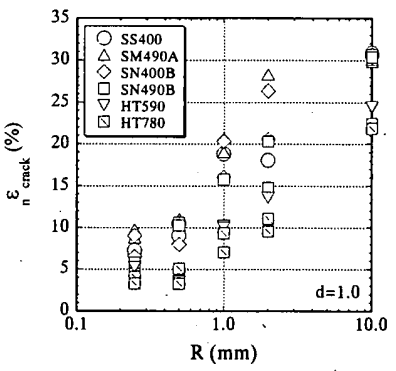

(b) $\varepsilon_{\mathrm{n}}$ crack $-\mathrm{R}$ 関係(全繋材)
図 4 き裂発生歪 $\varepsilon_{\mathrm{crack}}-$ 切欠半径 $\mathrm{R}$ 関係
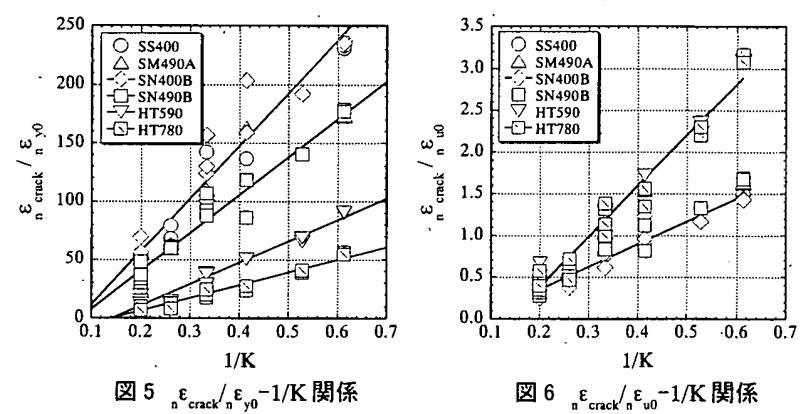

図 $6{ }_{n} \varepsilon_{\text {crack }_{n}} / \varepsilon_{\mathrm{u} 0}-1 / \mathrm{K}$ 関係

示す。 $400 \mathrm{~N}$ 級鋼が最も高い值を示し、最大耐力の大きい素材ほど 小さい值を示す傾向にある。全ての素材で $1 / \mathrm{K} の$ 増加に伴い一様に 增加しており、その勾配も $400 \mathrm{~N}$ 級鋼が最も大きい。鋼材の初期弾 
性剛性は、素材によらずほぼ $210\left(\mathrm{kN} / \mathrm{mm}^{2}\right)$ であり降伏公称応力度 ${ }_{n} \sigma_{\mathrm{y} 0}$ の高い素材ほど降伏公称歪度 ${ }_{\mathrm{n}} \varepsilon_{\mathrm{y} 10}$ が大きくなり、延性き裂発生 公称歪 $\varepsilon_{\mathrm{n}}$ crack に対する比は小さくなる。つまり、高張力鋼は延性き裂 発生公称歪 $\varepsilon_{\mathrm{crack}}$ も小さく降伏応力度も高いため, 許容応力度設計法 のように降伏公称歪 $\varepsilon_{\mathrm{y} 0}$ を基準とした場合、延性き裂発生までに大 きな塑性変形は望めず安全性の余裕度が小さい。

図6に延性き裂発生公称歪 $\varepsilon_{\mathrm{n}}$ rack を各素材の最大公称応力度時の歪 度 ${ }_{\mathrm{n}} \mathrm{v} 0_{\mathrm{v} 0}$ で無次元化した值と弾性応力集中係数の逆数 $1 / \mathrm{K}$ の関係を示 す。1/Kが小さい場合は素材間で大きな違いは見られず ${ }_{n} \varepsilon_{\text {crack }_{n}{ }^{\prime} \varepsilon_{\mathrm{u} 0}}=0.5$ 付近に值が分布している。現在の新耐震設計法での柱梁接合部の設 計においては、梁端部が素材の最大耐力を発揮し、最大公称応力度 時の歪度 $\varepsilon_{\mathrm{n}}$ ま ることを前提としているが、応力集中係数が高い場合にはそれ以前 に延性き裂が発生しており、期待する塑性変形能力を発揮する以前 に脆性破壊が起こることが考えられ、危険側の評価となっている。

\section{3. 有限要素法解析による断面内応力歪状態の把握}

\section{3-1. 解析手法概要}

実験により延性き裂発生公称歪 $\varepsilon_{\mathrm{n}}$ crack $は$ 、素材, 切欠形状の違いに より大きく異なることが観測され、延性き裂発生条件を検討するた めには、素材及び形状により異なる試験片内部の忘力 - 歪場を正確 に捉えることが必要である。そこで、実験で行った全ての試験片に 対して有限要素法解析を行った。使用した解析プログラムは

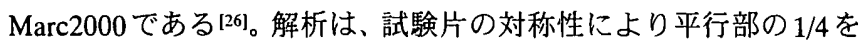
モデル化して行った。図7(a)にR0.50-d1.0の試験片の要素分割、図 7(b) に延性き裂発生点となる切欠底近傍の要素分割を拡大して示 す。応力, 歪が集中する切欠底付近の要素は他の部位に比べ細かく した。解析に使用した要素は 4 節点からなる 4 辺形軸対称要素であ る。境界条件は図に示すように $\mathrm{x}=0$ で $\mathrm{x}$ 方向変位が $0, \mathrm{y}=0$ で $\mathrm{y}$ 方向 変位が 0 の条件である。荷重条件は $\mathrm{x}=15(\mathrm{~mm})$ の自由端に $\mathrm{x}$ 方向の 一様な強制変位を漸増させるものとした。材質は等方等質であり等 方硬化則に従うものとし、組合せ忘力下での降伏条件はMisesの降 伏条件を採用した。また、塑性歪の増分に関しては歪増分理論に従 いPrandtl-Reussの流れ則を適用した。各素材の応力 - 歪特性は、平 滑素材引張試験の断面変化から得られた最小断面内平均真応力度 ${ }_{t} \sigma$ - 真歪度, $\varepsilon$ 関係を用いた。尚、解析においてき裂発生は考慮して いない。

\section{3-2. 解析結果の妥当性}

図 8 に SN490B-R0.50-d1.0 の公称応力度 ${ }_{n} \sigma^{-}$歪度 ${ }_{n} \varepsilon$ 関係の実験值 々解析値の比較を示す。解析值は延性き裂発生点付近まで実験值と よい対応を示している。延性き裂発生後の差は、解析ではき裂発生 を考慮にいれておらず延性き裂発生による断面欠損を再現できない ためだと考えられる。他の素材, 形状についても同様の結果が得ら れており、解析より得られるき裂発生時の切欠底断面内の応力-歪 状態も実験値とよい対応を示すと考えられる。

\section{3-3. 切欠底断面内応力 - 歪状態の把握}

既往の研究[18],[19]より延性き裂の発生は、介在物から発生したミク ロボイドの成長, 連結によって起こることが知られている。また、ボ イドの成長は応力三軸度の上昇によって促進され、延性き裂発生時 の限界塑性歪は応力三軸度の影響を受けることが知られている ${ }^{[2] 。}$

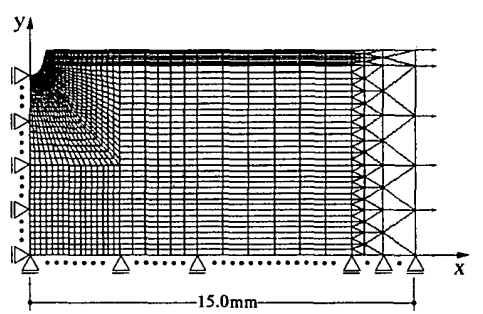

(a) 試験片の要素分割

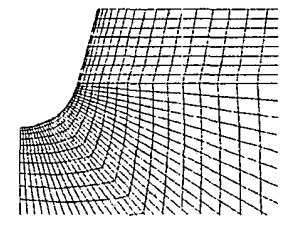

(b) 切欠底近傍0)要素分割
図 7 FEM 解析における要素分割 (R0.50-d1.0)

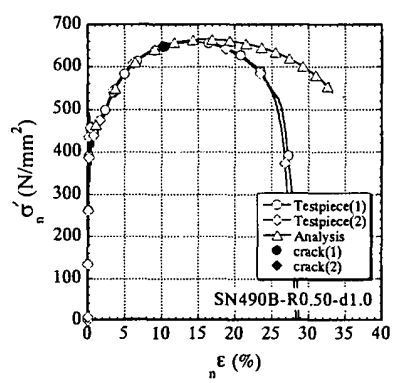

図 8 実験値と解析值の比較
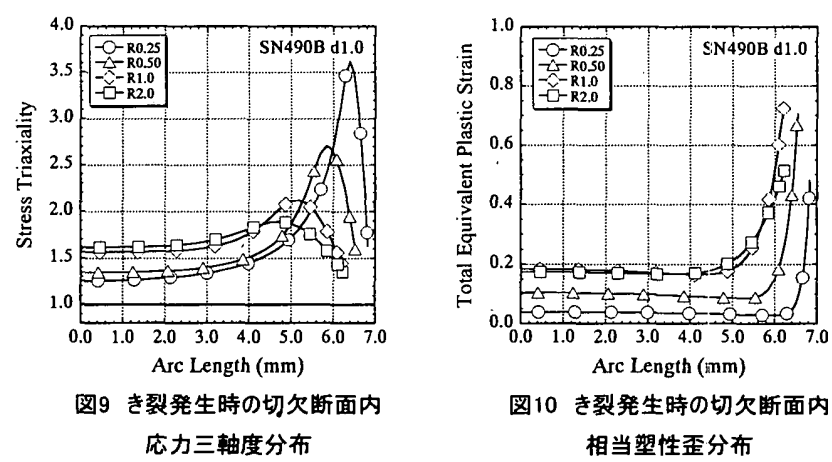

図10 き裂発生時の切欠断面内 相当塑性歪分布

そこで、延性き裂発生時の切欠底を通る最小断面内の応力三軸度と 相当塑性歪分布を既往の研究[11],[13],[21],[28] と同様に求めた。応力三軸 度 $S$ は多軸拘束の程度を表す指標として、次式(3)で与えられる。 $\ll$ Stress Triaxiality 》

$$
S=\frac{3 \sigma_{m}}{\sigma_{e q}}=\frac{\sqrt{2}\left(\sigma_{1}+\sigma_{2}+\sigma_{3}\right)}{\sqrt{\left(\sigma_{1}-\sigma_{2}\right)^{2}+\left(\sigma_{2}-\sigma_{3}\right)^{2}+\left(\sigma_{3}-\sigma_{1}\right)^{2}}}=
$$

ここで、

$$
\begin{aligned}
& \sigma_{m}=\frac{\sigma_{1}+\sigma_{2}+\sigma_{3}}{3} \\
& \sigma_{e q}=\frac{1}{\sqrt{2}} \sqrt{\left(\sigma_{1}-\sigma_{2}\right)^{2}+\left(\sigma_{2}-\sigma_{3}\right)^{2}+\left(\sigma_{3}-\sigma_{1}\right)^{2}}
\end{aligned}
$$

$\sigma_{1}, \sigma_{2}, \sigma_{3}:$ 主応力

$\sigma_{m}:$ 平均垂直応力 (静水圧), $\sigma_{e q}:$ Mises の相当応力 相当塑性歪 $e_{e q}$ は式 (4)で定義されたものである。

« Total Equivalent Plastic Strain 》

$$
\begin{aligned}
& e_{e q}=\frac{\sqrt{2}}{3} \sqrt{\left(e_{1}-e_{2}\right)^{2}+\left(e_{2}-e_{3}\right)^{2}+\left(e_{3}-e_{1}\right)^{2}} \\
& e_{1}, e_{2}, e_{3} \text { : 主歪 }
\end{aligned}
$$

図9に延性き裂発生時のSN490Bの切欠底を通る最小断面内応力 三軸度分布、図 10 に相当塑性歪分布を示す。ただし、本研究は脆 性破断の起点となる応力集中部における延性き裂の発生を対象とし 
ているため、切欠底表面で延性き裂が発生しなかったR10.0は除い て示した。なお、Arc Lengthは試験片中央部からの距離を現してい る。図9から分かるように、切欠半径 Rが小さいほど切欠底方向に 応力三軸度 $S$ のピークを示す部分が推移し、切欠底の応力三軸度 $S$ もそれに伴って高い値を示している[11],[13],[22]。また、第2 章で述べ たように切欠半径Rが大きいほど延性き裂発生までに歪が進行して おり、試験片中央部の応力三軸度 $S$ は高い値を示している。図10か ら分かるように、形状によらず切欠底で相当塑性歪 $e_{e q}$ が最も高い 值を示しており歪が集中している。切欠半径Rが大きいほど延性き 裂発生までに歪が進行し、試験片中央部の相当塑性歪 $e_{e q}$ は大きい 值を示すが、延性き裂発生点である切欠底の值は切欠半径 $\mathrm{R}$ 明確 な相関は見られない。これらの傾向は全ての素材で同様であった。

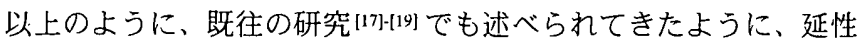
き裂は断面内の応力三軸度 $S$ あるいは相当塑性歪 $e_{c q}$ がある一定值 に達した時に生じると言うものではなく、断面内に生じている応力 三軸度 $S$ 之相当塑性歪 $e_{e q}$ との相互関係で生じるものであると考え られる。

\section{3-4. 既往の延性き裂発生条件を用いた考察}

図 11 に、今回の実験結果と桑村ら [11],[12]によって提案された延性 き裂発生条件を示す。図 11 から分かるように提案されている延性 き裂発生条件よりも早期にき裂が発生している試験体が多く見ら れ、危険側の評価となっている。

豊田らも同様に、延性き裂発生を支配するパラメー夕として応力三 軸度 $S$ と相当塑性歪 $e_{e q}$ をあげている[13]。延性き裂が切欠底に発生 する場合、延性き裂発生点となる歪集中部位の相当塑性歪 $e_{e q}$ が一 定值 $e_{e q}=1.0$ に達すると延性き裂が発生するという条件を提案してい るが、今回の実験においては図 10 を見ると分かるように、ほとん ど相当塑性歪 $e_{e q}=1.0$ に達する以前に延性き裂が発生している。石川 らの提案はSN490Bの単一素材について確認されたものであり、今 回の解析においては同形状において素材による切欠底の応力三軸度 $S$ - 相当塑性歪 $e_{e q}$ 関係に大きな違いは見られなかったが、延性き裂 発生条件となる相当塑性歪 $e_{e q}$ の一定值での推定は、多様化する素 材との対応、確認等の必要があると考えられる。

\section{4. 構造用鋼材の延性き裂発生条件}

\section{4-1. 切欠底における相当塑性歪 - 応力三軸度関係}

延性き裂は、応力三軸度 $S$ と相当塑性歪 $e_{e q}$ が相互に作用し、あ る条件に達した時に発生すると考えられる[17]-[19]。そこで、切欠底 における延性き裂発生条件を正確に求めるためには、豊田ら [13],[14] も指摘するように、切欠底表面極近傍についての応力三軸度 $S$ と相 当塑性歪 $e_{e q}$ の関係を明らかにする必要がある。ここでは延性き裂 が、切欠底表面から発生した形状について相当塑性歪 $e_{e q}$ 応力三軸 度 $S$ 関係に着目し延性き裂発生条件の提案を行う。図 12(a)に SN490Bについて全形状を、図12(b)に全素材についてR0.50-d1.0の 形状について切欠底における相当塑性歪 $e_{e q}$-応力三軸度 $S$ 関係及び き裂発生点を示す。

図12(a)から分かるように、切欠半径 Rが小さいほど切欠底にお ける多軸拘束が強く、応力三軸度 $S$ 高く保ちながら相当塑性歪 $e_{c a}$ が進展し、切欠半径 Rが大きいと需の進行に伴い応力三軸度 $S$ は低 下している。また、延性き裂発生時の相当塑性歪 $e_{c q}$ の值に切欠半

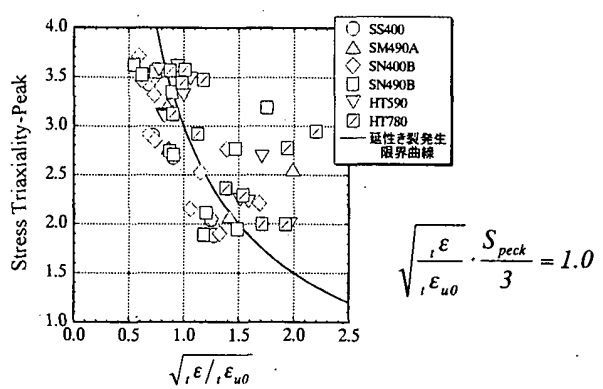

図 11 文献[11]による延性き裂発生条件

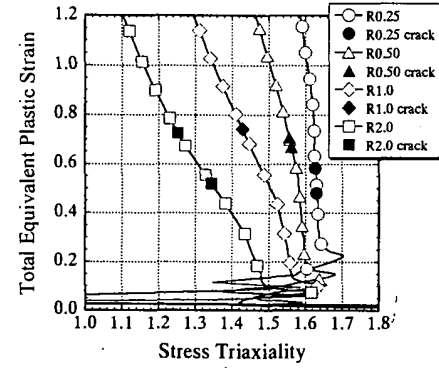

(a) SN490B

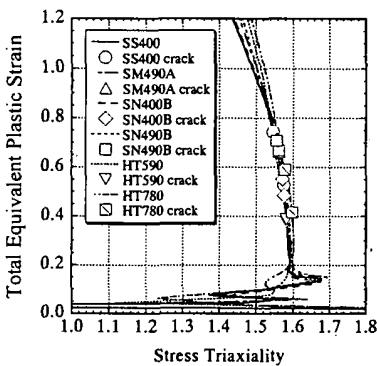

(b) 全素材(R0.50-d1.0)
图 12 切欠底における相当塑性歪 $e_{e q}-$ 応力三軸度 $S$ 関係

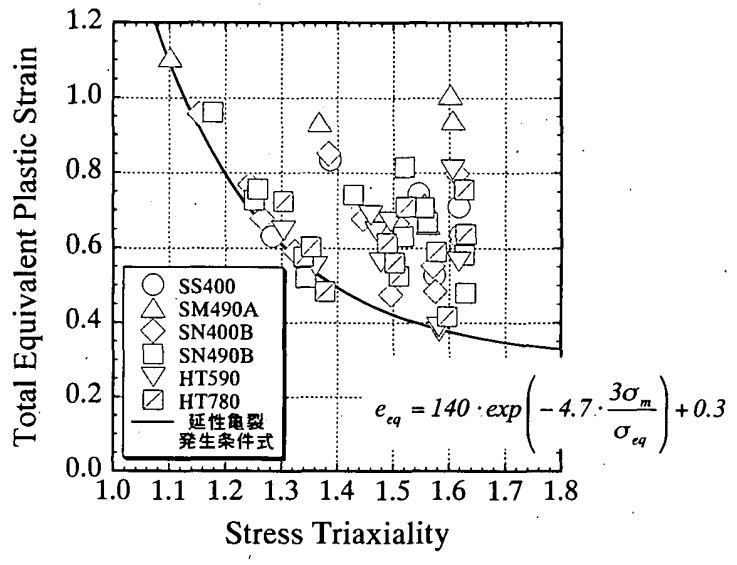

图13 延性き裂発生条件

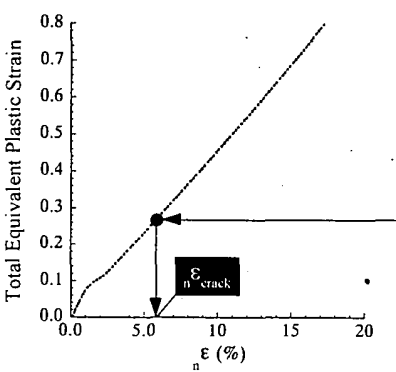

(a) 切欠底における $e_{e q}-$ 公称歪 ${ }_{\mathrm{a}} \varepsilon$ 関係

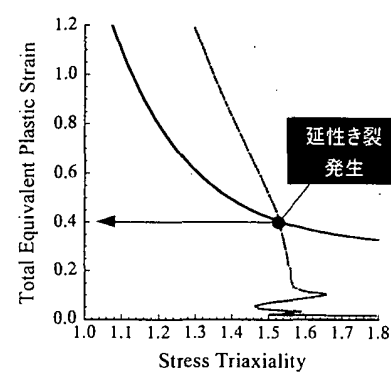

(b) $e_{e q}-S$ 曲線

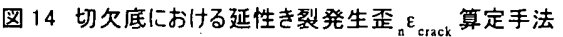

径 R との明確な相関は見られない。このことは、全ての素材につい て同様に言える。図12(b)加分かるように、相当塑性歪 $e_{c q}$ 応力 三軸度 $S$ 関係は素材によらずほぼ同じ曲線を描いており、素材の影 響は小さいと考えられる。延性き裂発生時の相当塑性歪 $e_{c q}$ の值は。 塑性変形能力に乏しい高張力鋼が他の軟鋼に比べて低い値を示す傾 向があるが明確ではなく、素材特性との相関も見られなかった。 


\section{4-2. 延性き裂発生条件式の提案}

図13に全素材の延性き裂発生時の相当塑性歪 $e_{c q}$-応力三軸度 $S$ 関 係を示す。応力三軸度 $S$ の高い範囲では、相当塑性歪 $e_{c q}$ が $0.4 \sim 1.0$ の間に広く分布し、応力三軸度 $S$ の低下に伴い相当塑性昰 $e_{c q}$ の值は 高い值を示す傾向が見られる。今回の実験結果及び既往の研究[8\}-[16] においても見られたように、延性き裂の発生は多少のばらつきを伴

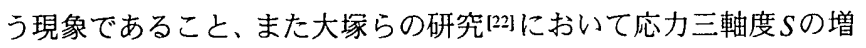
加に従い延性き裂発生時の相当塑性歪 $e_{e q}$ は 0.3 程度の下限值をとる ことが示されていることを考慮し、安全側の評価としてこれらのプ ロットを包絡する曲線を延性き裂発生条件と定義し次式 (5) を得る。

$$
e_{e q}=140 \cdot \exp \left(-4.7 \cdot \frac{3 \sigma_{m}}{\sigma_{e q}}\right)+0.3
$$

図 14 に切欠底における延性き裂発生歪 $\varepsilon_{\mathrm{n}}$ crack 14(b) に示す相当塑性歪 $e_{e q}$ - 応力三軸度 $S$ 関係と式(5)で得られる延 性き裂発生条件曲線の交差する点が延性き裂発生点となる[11]-[15]。 そして、ここで得られた延性き裂発生点の相当塑性歪 $e_{e q}$ を図14(a) に示す相当塑性歪 $e_{e q}{ }^{-}$公称歪度 ${ }_{n} \varepsilon$ 関係にシフトさせることで延性き 裂発生歪 $\varepsilon_{\text {crack }}$ を求めることができる。

新耐震設計法での保有耐力接合部では、梁端部が鋼材の最大耐力 を発揮することを前提としているが、兵庫県南部地震では接合部の 形状的不連続部に多軸拘束、歪が集中することにより脆性破断が発 生し、最大耐力を発揮することなく崩壊に至った鋼構造建築物が存 在した。その後、ノンスカラップエ法など応力集中を避ける改良がな されてはいるが、接合部の性質上、形状的不連続部が存在すること は必然であり、脆性破断を考慮した接合部耐力の評価が必要であ る。脆性破壊は、形状的不連続部において延性き裂が発生し、塑性 変形の過程においてき裂が安定的に成長、その大きさがある限界に 到達することで急激に破断に転化する現象である[2],[3]。延性き裂発 生防止は、脆性破断を考虑した最も安全側の設計クライテリアとして 適応が考えられる[2],127]。そこで、設計段階において柱梁接合部を想 定して有限要素法解析を行い、エンドタブやスカラップ底等の延性き 裂が発生する可能性のある部位に着目し、その点における相当塑性 歪 $e_{e q}$-応力三軸度 $S$ 曲線を求めることができれば、その曲線と式(5) による延性き裂発生条件曲線との交点が延性き裂発生点となる。こ の時点での歪を延性き裂発生限界歪とすると、地震外部入力が作用 したことによる注目部位に生じる歪をこの限界歪以下に抑えること ができれば、延性き裂が発生することはなく脆性破壊は防止できる 考えられる[2],[27]。

\section{5. 構造用鋼材の延性き裂発生歪推定式の提案 5-1. 延性き裂発生に及ぼす寸法効果}

今回の実験では、切欠底最小断面直径 2a $14 \mathrm{~mm}$ で一定として 切欠半径 $\mathrm{R}$, 深さ $\mathrm{d}$ 変化させて延性き裂発生実験を行った。しか し、実際の接合部を想定した場合、形状は様々であり寸法による影 響があると考えられる。そこで、寸法の影響を把握するため R1.0d1.0-2a14 基準として切欠半径 $\mathrm{R}$, 深さd, 断面直径 $2 \mathrm{a}$ を比例的に变 化させ解析を行った。表 3 に解析パラメー夕の組合せ、図15(a)に解

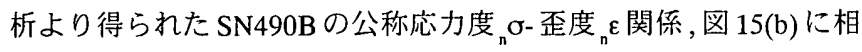
当塑性歪 $e_{e q}$-応力三軸度 $S$ 関係を示す。図15(a)から分かるように、 最大耐力付近までは大きな違いは見られない。しかし、それ以降の
表3 解析パラメータの組合せと延性き裂発生歪推定值

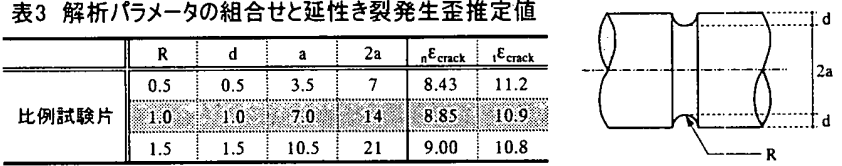

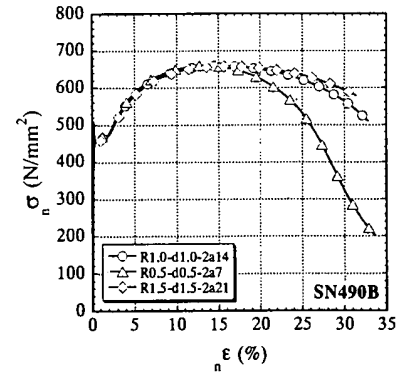

(a) 公称応力度 $\mathrm{g}-$ 歪度 $\mathrm{E}$ 曲線

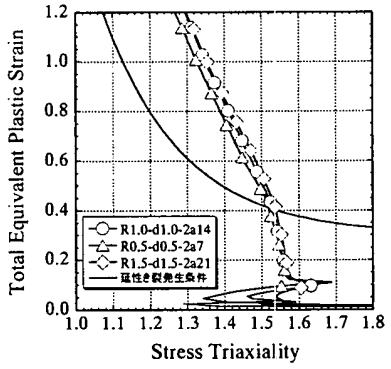

(b) $e_{\text {eq }}-S$ 曲線
図 15 き裂発生に及ほす寸法効果

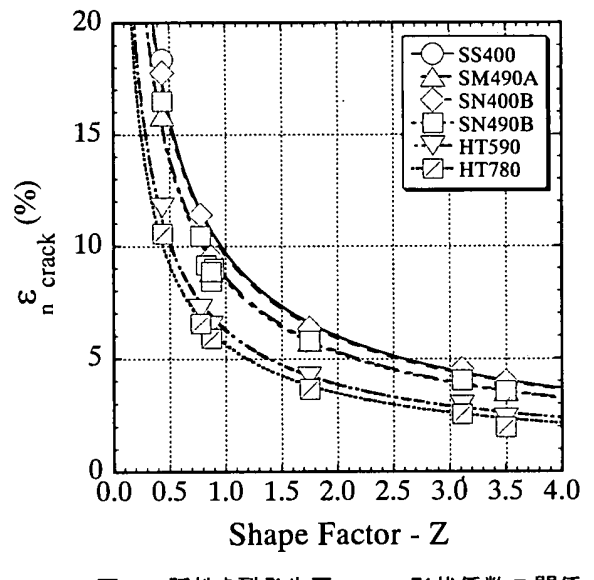

图 16 延性き裂発生歪 $\mathrm{E}_{\mathrm{crack}}$ - 形状係数 Z 関係

表 4 材料定数 C

\begin{tabular}{c||cccccc}
\hline Material & SS400 & SM490A & SN400B & SN490B & HT590 & HT780 \\
\hline \hline C & 9.73 & 8.64 & 9.59 & 8.52 & 6.29 & 5.66 \\
\hline
\end{tabular}

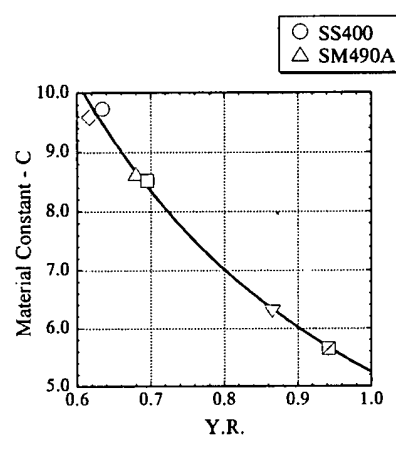

（a）材料定数 C- 降伏比 Y.R. 関係 $\diamond$ SN400B $\nabla$ HT590 一係数C-推定式

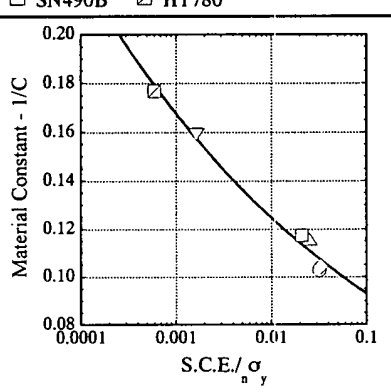

(b) 材料定数 $1 / \mathrm{C}$ -
修正補エネルギー比 S.C.E. $/ \mathrm{n} \sigma_{\mathrm{y}}$ 関係

图 17 材料定数 Cと素材特性の関係

応力低下には形状による違いが見られ、基準試験片(R1.01-d1.0-2a14) と比較すると、0.5 倍比例試験片 (R0.5-d0.5-2a7) は他の 2 形状に比 ベ耐力低下が著しく、1.5 倍比例試験片 (R1.5-d1.5-2a21) は、僅かで はあるが而扵力低下は抑えられており、最大耐力以降の耐力低下は試 験片形状が大きいほど抑えられる傾向が見られる。図15(b)から分 
かるように、相当塑性歪 $e_{c q}$-応力三軸度 $S$ 関係にほとんど差は見ら れず、試験片を比例的に変化させた場合の寸法の影響はないと言え る[9]:\{11]。

図 15(b)による延性き裂発生条件曲線と相当塑性歪 $e_{c q}$ - 応力三軸 度 $S$ 関係との交点より得られる延性き裂発生歪推定値を表 3 に示 す。これをみると、延性き裂発生歪はほとんど変わらず寸法の影響 は小さいといえる[9],[13]。よって、実際の接合部等を想定して延性き 裂発生歪を推定する際には、想定される形状を比例的に変化させて 解析を行い検討を行っても問題ないと考えられる。

\section{5-2. 延性き裂発生歪推定式}

接合部を想定して有限要素法解析を行い、延性き裂が発生する可 能性のある部位に注目し、その点の相当塑性歪 $e_{e q}$-応力三軸度 $S$ 曲 線と式(5)による延性き裂発生条件曲線から発生歪を予測するこ之 は可能である。重要構造物において、この方法から延性き裂発生歪 を求め、塑性変形の限界点として考慮されることが望まれるが、通 常の設計レベルにおいて全ての接合部について解析を行うことは実 用性に欠け、簡便な方法による延性き裂発生歪の推定が求められ る。そこで、柱梁接合部における延性き裂発生歪推定の基礎的段階 として試験片形状,素材特性を考虑した延性き裂発生丕推定式の提 案を行う。

形状によって異なる相当塑性歪 $e_{c q}$ - 応力三軸度 $S$ 関係と式 (5) で 表される延性き裂発生条件曲線の交点から得られる各素材の延性き 裂発生歪 $\varepsilon_{\mathrm{n}}$ crack と次式 (6) で定義する形状係数 $Z$ との関係を図 16 に 示す。

$$
Z=\frac{a}{a+d} \cdot \frac{d}{R}
$$

全ての素材において延性き裂発生歪 $\varepsilon_{\text {crack }}$ は形状係数Zの増加に伴っ て小さくなっている。また、延性き裂発生歪 $\varepsilon_{\mathrm{n}}$ crack 1 塑性変形能力 に乏しい高張力鋼が軟鋼に比べて小さくなっている。図に示される 回帰線は次式 (7) で数式表示できる。

$$
{ }_{n} \varepsilon_{\text {crack }}=C \times Z^{(-0.70)}
$$

式(7)に含まれるCは各素材の材料定数となる。表 4 に各素材の材 料定数を示す。材料定数Cは各素材の延性き裂発生に関する特性值 であり、素材の力学的特性と相関があると思われる。特に、素材の 塑性変形能力を表す指標と相関があると考える。そこで、塑性変形 能力を示す指標として素材引張試験より得られる降伏比Y.R.と修正 補エネルギー比 S.C.E./ $\sigma_{\mathrm{y}}$ を取上げ、材料定数 C との関係を次に考 察する。

図 17(a) は材料定数 C と降伏比 Y.R.の関係、図 17(b) は材料定数 Cの逆数 $1 / C$ と修正補エネルギー比 S.C.E./ $/ \sigma_{\mathrm{y}}$ の関係を示す。図に 示すように材料定数 Cは降伏比 Y.R., 修正補エネルギー比 S.C.E. $/ \mathrm{n} \sigma_{\mathrm{y}}$ とよい相関を示していることが分かる。図中の実線は最小自乗法を 用いた回帰線であり、回帰曲線はそれぞれ次式(8),(9)によって数式 表示できる。

$$
\begin{aligned}
& C=5.25 \times Y \cdot R .^{(-1.30)} \\
& C=1.4 .5 \times\left(\frac{\text { S.C.E. }}{{ }_{n} \sigma_{y}}\right)^{0.128}
\end{aligned}
$$

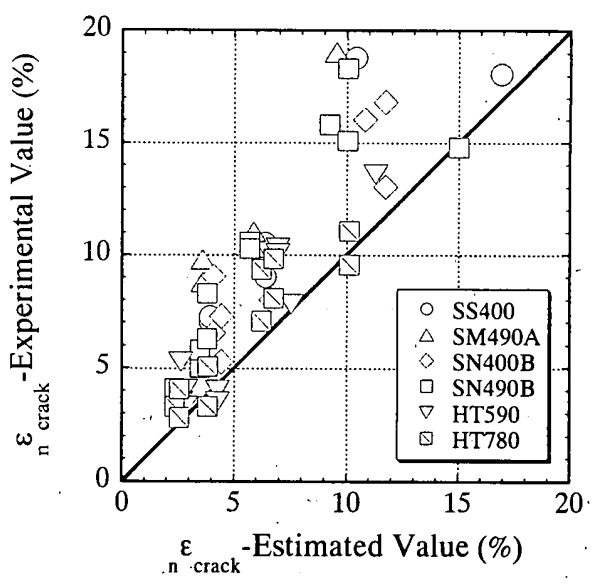

（a）降伏比 Y.R. を用いた推定

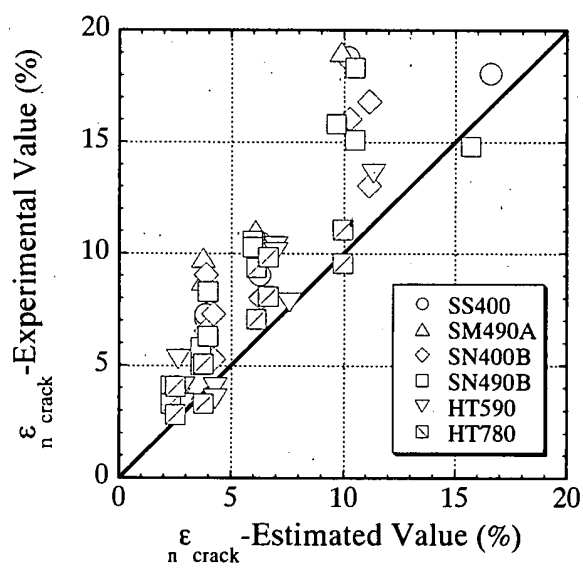

（b）修正補エネルギー比 S.C.E./n。

图 18 延性き裂発生歪 $\varepsilon_{\mathrm{n}}$ crack 実験値 - 推定値の比較

式 (8),(9) は、各素材の材料定数 C の推定式となる。これら推定式 (7),(8)、(7),(9)を用いることで、素材特性，切欠形状を考慮した延 性き裂発生歪推定式 (10),(11) を得る。

$$
\begin{aligned}
& { }_{n} \varepsilon_{\text {crack }}=\left(5.25 \times Y . R^{(-1.30)}\right) \times\left(\frac{a}{a+d} \cdot \frac{d}{R}\right)^{(-0.70)} \\
& { }_{n} \varepsilon_{\text {crack }}=\left(14.5 \times\left(\frac{\text { S.C.E. }}{{ }_{n} \sigma_{y}}\right)^{0.128}\right) \times\left(\frac{a}{a+d} \cdot \frac{d}{R}\right)^{(-0.70)} \cdots
\end{aligned}
$$

式(10),(11)を用いることで、代表素材引張試験より得られる各素 材の降伏比(Y.R.)或いは修正補エネルギー比(S.C.E./n $\sigma_{y}$ )を用いるこ とで、幾何学的形状 $(\mathrm{R}, \mathrm{d}, \mathrm{a})$ が既知であれば、切欠を有した材の切欠 底表面における延性き裂発生公称歪 $\varepsilon_{\mathrm{n}}$ crack を求めることができる。

提案した式(10),(11)から分かるように、降伏比Y.R.の小さい素材 或いは修正補エネルギ一比 S.C.E./ $/ \sigma_{\mathrm{y}}$ の大きい素材ほよ゙、延性き裂 発生までに許容できる歪量が大きいことが分かる。

\section{5-3. 延性き裂発生歪の推定精度}

素材特性,切欠形状を考慮した延性き裂発生歪推定式(10),(11)を 提案した。図 18 に式 (10),(11) で求められる延性き裂発生歪推定值 と実験により得られた值との比較を示す。眓18(a) は降伏比 Y.R. を 用いた推定結果であり、図18(b)は修正補エネルギー比 S.C.E. $/ \sigma_{\mathrm{n}} \sigma_{\mathrm{y}}$ を 
用いた推定結果である。実験值の安全側を包絡する延性き裂発生条 件式(5)を用いて式(10),(11) を提案しているため、延性き裂発生時 の相当塑性歪 $e_{e q}$ が高張力鋼よりも全体的に大きい值を示す軟鋼で はより安全側の評価となっている。しかし、延性き裂発生時の相当 塑性歪 $e_{e q}$ に素材特性の明膫な相関をみることができなかったこと、 及び延性き裂発生は不確定性を伴った現象であることを考慮する と、図に示すように推定值は実験値の下限值を包絡しており、延性 き裂発生歪 $\varepsilon_{\mathrm{n}}$ crack を安全側に評価している。よって、提案した延性き 裂発生歪推定式は推定式として妥当であると考えられる。

提案した延性き裂発生歪推定式は試験片レベルのものである。実 際の柱梁接合部では、使用素材, スカラップやエンドタブ等の形状, フ ランジ幅厚比,梁スパン(モーメント勾配), 溶接熱影響等、延性き裂発 生に及ぼすと思われる要因が多数存在し、複雑に関与する。よっ て、今後の研究課題としてこれらの因子の影響を考慮した簡便な延 性き裂発生歪推定式の提案が必要である。

\section{6. 結論}

建築に用いられる構造用鋼材を対象に切欠を有する丸棒試験片を 用いて引張試験及び有限要素法解析を行い、延性き裂発生条件につ いて考察し、以下の結論を得た。

(1) 切欠底における応力三軸度と相当塑性歪は切欠形状の影響を受 け、切欠半径が小さいほど三軸応力拘束が強くなる。相当塑性歪の 值に切欠半径との明確な相関は見られなかった。

（2）切欠底の相当塑性歪 - 応力三軸度関係は、切欠半径が小さいほ ど応力三軸度が高い值を保ちながら相当塑性歪が進行する。素材特 性が相当塑性歪 - 応力三軸度に及ぼす影響は小さい。

(3) 延性き裂発生時の相当塑性歪 - 応力三軸度関係は、応力三軸度 の上昇に伴い相当塑性歪が低下する傾向が見られる。今回、実験值 を包絡する曲線を延性き裂発生条件式として提案した。

（4）素材特性及び切欠の幾何学的形状から、切欠底で発生する延性 き裂発生歪を予測できる延性き裂発生歪推定式を提案した。

（5）応力集中部での延性き裂発生に及ぼす重要な素材特性は、降伏 比或いは修正補ネルギ一比であることを明らかにした。降伏比が小 さいほど或いは修正補エネルギー比が大きいほど延性き裂が発生す るまでに許容できる変形量は大きい。

\section{謝辞}

本研究で使用いたしました鋼材は新日本製鐵株式曾社より提供していた だきました。また、本研究は中部電力株式会社との共同研究ありま す。付してして感謝いたします。また、本論文の第二筆者は日本学 術振興会特別研究員です。ここに記して感謝いたします。

\section{《参考文献》}

[1] 日本建築学会近畿支部鉄骨㩐造部会 : 1995 年兵庫県南部地震鉄骨棈造建築物被害调查報告, 1995.05

[2] 日本建築学会棈造委員会 : 鉄骨の破壊睍棌はどこまで解明されたのか、当面の対策資料， 2000 年度日本建築学会大会 (東北) パネルディスカッション資料,2000.09

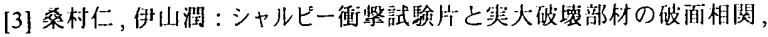
日本建築学会样造系諭文集,No.508,pp.127-133,1998.06

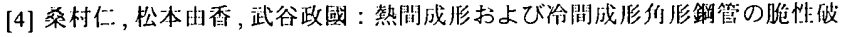
壊，日本建築学会槛造系諭文集,No.494,pp.129-136,1997.04

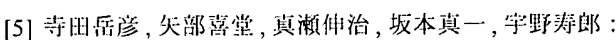
動的荷重下における鉄骨柱梁接合部の力学们举動に関する实験的侏究， 日本建築学会满造系僵文集,No.492,pp121-129,1997.02

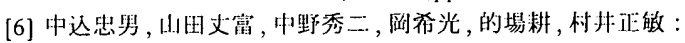
高速載荷による柱梁溶接接合部の力学的性能に関する奏験的研究, 日本建築学会满造系墖文集,No.499,pp115-122,1997.09

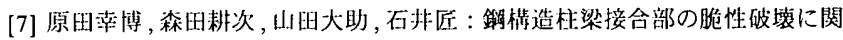
する研究，日本建築学会篟造系論文集,No.535,pp141-148,2000.09

[8] 桑村仁,秋山宏 : 延性き铱発生ひずみに及ほす冷間塑性加ての影響, 日本建築学会構造系諭文集,No.454,pp.171-178,1993.12

[9] 桑村仁, 秋山宏 : 延性き裂発生ひずみに及ぼす寸法の影響, 日本建築学会棈造系論文集,No.458,pp.119-125,1994.04

[10] 桑村仁, 松本由香 : $800 \mathrm{MPa}$ 鋼の延性龟裂発生歪に及ぼす歪公!配の影響， 日本建築学会大会学術請演梗概集 (北海道),pp.345-346,1995.08

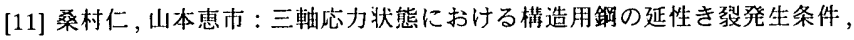
日本建筑学会構造系論文集,No.477,pp.129-135,1995.11

[12] 稻葉雄一郎, 桑村仁 : 切久き付き鋼板の応力 - ひずみ解析による有限要素 法の適応性と延性き裂発生条件 (鉄骨接合部の忘力・ひずみ状態 その2) 日本建築学会構造系論文集,No.534,pp.137-144,2000.08

[13] 石川信行, 小林泰男, 梁原政好, 大沃紘一, 豊田政男：絽返し荷重下におけ る構造用鎆の延性き裂発生挙動, 鉄と鋼,Vol.85,pp.71-77,1999.04

[14] 安田修, 広野正彦, 横田冒樹, 大畑充, 豊田政男: 大変形䋹返し荷重下での棈造用鉿の延性き裂発生限界の基碚的研究， 鋼㩐造年次論文報告集, 第 8 巻,pp425-432,2000.11

[15] 島鿓広志, 萩原行人 円周切欠丸棒試験による簡易延性き裂発生特性評価方の検討 - 鋼材の延性 き裂発生特性 第 1 報, 第 2 報, 溶接学会講演大会梗概集,Vol.55,pp.410-413,1994.10

[16] 島貫広志, 古谷仁志, 井上健裕, 小林順一, 馬㴊秀里 : 銅材および鉄骨造建 築の延性き裂発生限界,CAMP-ISIJ,Vol.9.pp.1172-1175,1996

[17] J.W.Hancock, A.C.Mackenzie : On the Mechanisms of Ductile Failure in High Strength Steels Subjected to Multi-Axial Stress-State, J.Mech. Phys. Solids,Vol.24,pp.147-169,1976

[18] F.A.McClintock : A Criterion for Ductile Fracture by the Growth of Holes, J.Appl.Mech., Vol.35,pp363-371,1968

[19] J.R.Rice,D.M.Tracey : On the Ductile Enlargement of Voids in Triaxial Stress Fields,J.Mech.Phys.Solids, Vol.17,pp.201,1969

[20] 小野徹郎, 佐藤篤司 : 金属系素材の応力 - 歪度関係の定式化, 日本建築学会構造系論文集,No.532,pp.177-184,2000.06

[21] A.C.MACKENZIE, J.W.HANCOCK, D.K.BROWN : ON THE INFLUENCE OF STATE OF STRESS ON DUCTILE FAILURE INITIATION IN HIGH STRENGTH STEELS, Engineering Fracture Mechanics, Vol.9, pp167-188, 1977

[22] 大塚昭夫, 宮田隆司, 西村誠二, 木村雅保, 馬刹宗人 : 低強度銅における延性破壊の発生に及ほす三軸志力度の影罄， 材料, 第 29 巻,第 322 号,pp.55-61,1980.07

[23] 西谷弘信：き裂における応力拡大係数に相当する、切欠きにおける応力 場の尺度，日本機珹学会論文集 (A 編), 第 48 巻 447 号,pp1353-1359,1983.11

[24] 西谷弘信, 野口博司：网周切欠きを有する高強度鋼の引張破断条件，日本 機械学会論文集 (A 編), 第 52 巻 477 号,pp1286-1289,1986.05

[25] 西田正孝：応力集中, 森北出版, 1967

[26] 任藤䉆司，小野徽郎：金属系素材の切欠強度砰価， 唋構造年次論文報告集,Vol.9,pp.125-132,2001.11

[27] 桑村仁, 稻葉雄一郎：鉄骨接合部の平面ひずみ状態におけるは力三軸度と ひずみ集ゆ率( 鉄县接合部の応力・ひずみ状態にーその1), 日本建筑学会篟造系論文集,No.518,pp87-94 1999.04

[28] E.A.DAVIS,F.M.CONNELLY : Stress Distribution and Plastic Deformation in Rotating Cylinders of Strain-Hardening Material, Jurnal of Applied Mechanics,pp.25-30,1959.03 